Pérez, C., Fernández, C., Méndez, V., Méndez, P., \& Fernández, A. (2018).

Evolution of GDP and its impact on the pharmaceutical sector of Ecuador

Journal

(2007-2016). Journal of International Studies, 11(1), 288-296. doi:10.14254/2071-

of International

$8330.2018 / 11-1 / 22$

Studies

\title{
Evolution of GDP and its impact on the pharmaceutical sector of Ecuador (2007- 2016)
}

\section{Cristina Pérez}

Department of Social and Legal Sciences, SEK International

University

Ecuador

cristina.perez@uisek.edu.ec

bttps:/ / orcid.org/0000-0002-4154-5483

\section{Carlos Fernández}

Department of Social and Legal Sciences, SEK International

University

Ecuador

carlos.fernández@uisek.edu.ec

bttps:/ / orcid.org/0000-0003-0943-756X

\section{Vicente Méndez}

Department of Economic and Administrative Sciences, University of

Cuenca

Ecuador

vicente.mender@ucuenca.edu.ec

bttps://orcid.org/0000-0001-7497-5802

\section{Paola Méndez}

Department of Economic and Administrative Sciences, University of

Cuenca

Ecuador

paola.mendez@ucuenca.edu.ec

bttps:// orcid.org/0000-0002-3629-4771

\section{Angie Fernández}

Department of Economic, Administrative and Trade Sciences,

University of the Armed Forces ESPE

Ecuador

aafernandez2@espe.edu.ec

https:/ / orcid.org/0000-0001-6106-8576 
Abstract. In the last decade there has been an increase in Ecuador's GDP observed, despite the economic slowdown in 2015 and 2016. Likewise, there has been an increase in spending on health, especially in the public sector, supported by the legislative framework of Ecuador. The objective of the article is to determine the relationship between GDP and healthcare expenditures, both public and private, and also the the income and profits of the pharmaceutical industry. In addition, we intends to check whether the changes taking place in this Latin American country have had any effect on the degree of concentration in this sector, traditionally oligopolistic. The data were collected from government agencies. The processing of the collected information was carried out with the use of SPSS. In the course of these statistical analyses we have found evidence of the strong relationship between GDP and healthcare spending, both public and private, in connection with the performance of the pharmaceutical companies. Dominance of the oligopolistic features was corroborated, despite the evidences of the concentration decrease in the last ten years (2007-2016). The empirical study of the sample has demonstrated there is a strong relation of GDP with the income and profits of the pharmaceutical sector, as well as with health spending in general, among other results.

Keywords: pharmaceuticals, GDP, healthcare expenditures, economy, economic cycles

JEL Classification: E3, F4, O4

\section{INTRODUCTION}

Since 2003, the Ecuadorian state has significantly increased its investment and budgetary allocations into the healthcare sector. Only within the period between 2008 and 2012, spending on state healthcare increased by $243 \%$, thus assuming, per se, a quantitative increase in healthcare expenditure per capita (Carriel, 2012). Health is a human right recognized in Article 32 of the Constitution of Ecuador as of 2008, which has led to quantitative and qualitative changes in the national healthcare system, thus leading to free and guaranteed availability of basic medical services for all citizens. These transformations have had their contribution into the development of the country and have caused a greater distribution of benefits of the pharmaceutical sector, causing a direct impact in the increase of profits for the medical companies. Acquisition of drugs today is carried out through the National Public Procurement Service (Sercop) with the aim of obtaining rebate for purchases. According to the Social Investment Database in Latin America and the Caribbean developed by the Social Development Division of ECLAC in 2015, Ecuador invested $2.6 \%$ of its GDP in healthcare, thus becoming the eighth country in the region by the percentage of GDP invested in health, being surpassed by Trinidad and Tobago, Honduras, Paraguay, Jamaica, Uruguay, Nicaragua and Chile. In addition, the Twenty-Second Transitory Provision of the Constitution of Ecuador imposes, as a budgetary obligation, that this rate increases each year by $0.5 \%$ of GDP until reaching at least $4 \%$ of the gross domestic product. This marked objective is still far away from the actual situation in the country. One of the reasons for this constitutional breach is the crisis which is the result of the drop in oil prices, with its strong impact on public spending and its spillover effect throughout the economy, including the healthcare sector. 
According to figures provided by the Economic Commission for Latin America and the Caribbean (ECLAC), the Republic of Ecuador is one of the countries in the region that exceeds the average growth rate of the gross domestic product at constant prices from the period from 2007 to 2016. However, like in any other middle-income country, GDP has undergone significant fluctuations in the decade analyzed.

Between 2010 and 2014, Ecuador lived its "golden lustrum" (Pérez, 2017), marked by the rise in GDP. Then in 2015 a stage of decline began due to the dependence of the economy on hydrocarbon prices, that demonstrated a sharp drop at the international level (Fernández, 2017). Then, prices for raw materials affected the state budget, and also caused the decrease of incomes for all the companies directly linked to the oil sector. All these changes had their serious impact on trade balance, for it accumulated a negative balance of 11,618 million dollars between 2007 and 2016, according to the Central Bank of Ecuador.

According to the data offered by the Central Bank of Ecuador, behavior of GDP per capita follows the same trend as GDP overall. This indicator reached its peak in 2014, and then it started to have negative growth rates.

Public investments in infrastructure affects the economic growth of a country (Bravo, 2014), positively influencing the industrialization processes (Rodríguez et al., 2016). Similarly, several studies have shown there is high correlation between investment in strategic sectors and GDP growth, as well as improvements in the general conditions of the economy (Ahmadi \& Shahandashti, 2017; Galindo \& Sosvilla, 2012). This would explain the evolution of the gross domestic product in the Andean country, since public spending in Ecuador exceeded in 2016 the tripled amount of the same as of 2007. All this has been reflected in the positive behavior of other variables such as employment, remunerations, or patrimonial masses of the companies. Similarly, there was an increase in the share of income tax in GDP between 2010 and 2014, especially concentrated around corporate tax, assisted by the decline in tax evasion. These positive effects crystallized in the improvement in the Gini coefficient that meant greater equity among population (Méndez, et al., 2015). Likewise, this situation was favored by the considerable increase in oil prices until 2014, the core export product of Ecuador.

The pharmaceutical industry has been developing exponentially. Globalization contributed to its growth through opening of a large number of markets and creation of products that have increased the population welfare. The ten main exporting countries within the world pharmaceutical industry have increased their average growth rate by 3\% between 2010 and 2014 (González, 2015). The crisis in the developed economies has not slowed down the growth of this group worldwide (OMCE, 2014). Five of the ten most important pharmaceutical corporations in 2015 have American origin, and none of them is present in Ecuador. Only Novartis and Roche operate in this Andean country, possibly due to the significant level of regulation that affects, among other aspects, the pricing at the market (Acebo, 2015). The later factor also makes this country unattractive to large multinationals.

Global pharmaceutical statistics points to an increase in the total healthcare spending per capita in USD by almost 100\% between 2000 and 2011 (WHO, 2014). This is mostly due to the factor of population aging which generates a certain pressure to sell drugs at lower prices but paradoxically increase their consumption over time. Therefore, overall the pharmaceutical sector is only rising. In Latin America, during the period of 2014-2019, the annual growth in drug spending is expected to be between 4.8\% and 7.8\% (Acebo, 2015). According to previous studies, this sector is expected to increase its benefits by the year 2020 (PwC, 2012), especially in emerging and middle-income countries. Despite the possible risks for private companies such as the growth of generic drugs and the anticipation of their greater market share, the loss of patents from the best-selling markets and the crisis of disruptive innovation (OMCE, 2014), there are still many new business areas that can be exploited by the pharmaceutical industry, such as digital health tools. Currently, there are about 318,000 applications directly related to health problems, moreover, about 200 new apps are created every single day (IQVIA, 2017).

One of the major problems of the healthcare sector in developing countries, which includes the Andean country, is the need to import pharmaceutical products, due to insufficient volumes of domestic production 
(Ortiz et al., 2014), increasing negative effect on the balance of payments, as well as the forecasts that all these trends will only continue in the future (Qian, 2007), with serious effects on compliance with the social mission of national institutions and governments (Terán et al., 2017).

During the analyzed period, the number of firms in the sector has increased by $88 \%$, of which the majority are foreign companies. In 2011, the use of the International Financial Reporting Standards in Ecuador was approved, which meant support for the entry of multinational companies and "multi-country" companies, as this resulted in significant cost savings for all of them (Pérez et al., 2015).

The Alianza Pais governments have promoted change in the productive matrix driven by the sectors considered to be strategic, among which is also the pharmaceutical sector, which is treated today as the key to boosting development and decreasing national morbidity rate. The 2017-2021 National Plan for Good Living ratifies the pharmaceutical sector as one of the priorities in the new productive matrix (SENPLADES, 2017). In 2009 the public company ENFARMA EP was created, its main activity being production, marketing and research of generic medicines for internal consumption, especially for the public healthcare system and non-profit exportation, so that to help fighting some of the diseases with the greatest influence, such as respiratory diseases, gastric diseases, diabetes, cancer, among others (Acebo, 2015). However, on June 30, 2016, liquidation of this company was performed according to the Executive Decree 1103.

One of the major changes at Ecuadorian pharmaceutical market concerns the increase in generic drugs, following the general trend of the region (Fedesarrollo, 2015). Most of the local industry is dedicated to the production of this type of products. And this production is quite densely concentrated: only four laboratories cover $47 \%$ of Ecuadorian production (Acebo, 2015). Another change is the increase in GDP per capita, which allows citizens spend more on their consumption of goods. These drugs and other healthcare products are very much different from various other goods since they are often considered as the first necessity (Simó, et al., 2011; Baltagi \& Moscone, 2010). Therefore, they have an inelastic demand in relation to income level. Increase in the consumption of health-related products reduces mortality rates, especially in the most socially vulnerable populations, such as the elderly and the middle-aged (Miller \& Frech, 2000). In addition, increase in public spending in this sector, changes in the demographic pyramid and development of chronic diseases due to the sedentary lifestyle of more developed societies provides the pharmaceutical industry with additional development prospects.

Based on the foregoing, the objective of this research is to establish the relationship between GDP and healthcare expenditures, both public and private, and also income and profits of the pharmaceutical industry sector; as well as to check whether the most recent changes in Ecuador have had any effect on the degree of concentration in the pharmaceutical sector.

\section{METHODOLOGY AND RESULTS}

The data for the period 2007-2016 used for the present work have been extracted from different sources indicated in the following table:

Table 1

Origin of the data used in the study

\begin{tabular}{|c|c|}
\hline Variable & Source \\
\hline Utilities of pharmaceutical companies & Superintendence of Companies \\
\hline Revenue from pharmaceutical companies & Superintendence of Companies \\
\hline GDP per capita current prices & Central Bank of Ecuador \\
\hline Health expenditure per capita (US \$ at current prices) & World Bank \\
\hline Public Expenditure Health per capita & Expansion \\
\hline
\end{tabular}

Source: Self made 
The figures have been extracted from two databases. The first consists of the variables added for each of the years. The data of the Superintendence of Companies was collected in September of 2017. The information of the manufacturing companies was leaked and only those dedicated to the manufacture of pharmaceutical products, medicinal chemical substances and botanical products for pharmaceutical use were used. The figures of the companies refer to the active ones and they are modified according to the companies they give the information of the financial statements, so they can change over time, but not in a significant way. This database is small, so the normality of the macroeconomic variables was proved with the Kolmogorov-Smirnov test (Felipe, 1988), which shows that they behave in a normal way ( $>>0.05)$. For this same database, the Pearson correlation coefficient of the variables was calculated and the result appears in Table 2.

Table 2

Pearson correlations of the variables

\begin{tabular}{|l|c|c|c|}
\hline \multicolumn{1}{|c|}{$* * \mathrm{p}<\mathbf{0 , 0 1}$} & $\begin{array}{c}\text { Revenue from } \\
\text { pharmaceutical } \\
\text { companies }\end{array}$ & $\begin{array}{c}\text { Utilities of } \\
\text { pharmaceutical } \\
\text { companies }\end{array}$ & $\begin{array}{c}\text { Public } \\
\text { Expenditure } \\
\text { Health Per } \\
\text { Capita }\end{array}$ \\
\hline GDP per capita current prices &, $953^{* *}$ &, $896^{* *}$ &, $954^{* *}$ \\
\hline Health expenditure per capita (US \$ at current prices) &, $808^{* *}$ &, $788^{* *}$ &, $987^{* *}$ \\
\hline Public Expenditure Health Per Capita &, $841^{* *}$ &, $783^{* *}$ & 1 \\
\hline
\end{tabular}

Source: Authors' results. * indicates significance level at 0.10 level, ** indicates significance level at 0.05 level, *** indicates significance level at 0.01 level.

The data show a strong correlation between all the variables analyzed, being the most consistent "Expenditure in health per capita (US \$ at current prices)" with "Public Expenditure on Health Per Capita". Subsequently, the simple linear regression of the same fields was calculated, which shows that the independent variables explain significantly the dependent variables (Table 3).

Table 3

Regression analysis for the variables analyzed

\begin{tabular}{|c|c|c|c|c|}
\hline Independent variable & Dependent variable & R square & F & S.I.G. \\
\hline GDP per capita current prices & $\begin{array}{c}\text { Revenue from } \\
\text { pharmaceutical companies }\end{array}$ & 0,908 & 78,555 & 0 \\
\hline GDP per capita current prices & $\begin{array}{c}\text { Utilities of pharmaceutical } \\
\text { companies }\end{array}$ & 0,804 & 32,718 & 0 \\
\hline $\begin{array}{c}\text { Health expenditure per capita (US \$ at } \\
\text { current prices) }\end{array}$ & $\begin{array}{c}\text { Revenue from } \\
\text { pharmaceutical companies }\end{array}$ & 0,652 & 15,005 & 0,005 \\
\hline $\begin{array}{c}\text { Health expenditure per capita (US \$ at } \\
\text { current prices) }\end{array}$ & $\begin{array}{c}\text { Utilities of pharmaceutical } \\
\text { companies }\end{array}$ & 0,621 & 13,122 & 0,007 \\
\hline Public Expenditure Health Per Capita & $\begin{array}{c}\text { Revenue from } \\
\text { pharmaceutical companies }\end{array}$ & 0,707 & 14,496 & 0,009 \\
\hline Public Expenditure Health Per Capita & $\begin{array}{c}\text { Utilities of pharmaceutical } \\
\text { companies }\end{array}$ & 0,582 & 8,341 & 0,028 \\
\hline
\end{tabular}

Source: Authors' results. 
The other database consists of the financial statements of all the manufacturing companies, which includes the pharmaceutical sector, from which their respective income and individual profits were extracted from the analyzed period 2007-2016. With this second table what is sought is to know the dispersion of income and profits in the industry.

Table 4

Concentration of income around the 10 companies with the highest incomes

\begin{tabular}{|c|r|r|c|r|}
\hline Year & Total income of the & $\begin{array}{c}\text { Total income of 10 } \\
\text { companies with } \\
\text { sector }\end{array}$ & $\begin{array}{c}\text { \% of concentration } \\
\text { of income of the } \\
\text { sector in 10 } \\
\text { companies with } \\
\text { higher income }\end{array}$ & $\begin{array}{c}\text { Total income of } \\
\text { the rest of } \\
\text { companies }\end{array}$ \\
\hline 2007 & $464.371 .977,58$ & $393.183 .418,82$ & $85 \%$ & $71.188 .558,76$ \\
\hline 2008 & $566.030 .389,63$ & $457.452 .980,24$ & $81 \%$ & $108.577 .409,39$ \\
\hline 2009 & $636.787 .629,09$ & $524.923 .667,04$ & $82 \%$ & $111.863 .962,05$ \\
\hline 2010 & $768.680 .729,02$ & $589.226 .927,89$ & $77 \%$ & $179.453 .801,13$ \\
\hline 2011 & $890.222 .956,09$ & $679.002 .250,33$ & $76 \%$ & $211.220 .705,76$ \\
\hline 2012 & $979.984 .268,83$ & $764.340 .406,75$ & $78 \%$ & $215.643 .862,08$ \\
\hline 2013 & $1.043 .056 .642,89$ & $799.971 .162,29$ & $77 \%$ & $243.085 .480,60$ \\
\hline 2014 & $931.169 .175,22$ & $688.350 .397,19$ & $74 \%$ & $242.818 .778,03$ \\
\hline 2015 & $1.052 .852 .839,21$ & $760.573 .564,35$ & $72 \%$ & $292.279 .274,86$ \\
\hline 2016 & $959.034 .259,35$ & $683.249 .597,76$ & $71 \%$ & $275.784 .661,59$ \\
\hline
\end{tabular}

Source: Authors' results

The concentration of the sector around the ten companies with the highest income is strong but throughout the period it fluctuates. Regarding the concentration around profits, it has declined, but less with respect to income, as it is still high, as shown in Table 5.

Table 5

Concentration of profits around the 10 companies with the greatest benefits

\begin{tabular}{|c|c|c|c|c|}
\hline Year & $\begin{array}{l}\text { Total profits of the } \\
\text { sector }\end{array}$ & $\begin{array}{l}\text { Total profits of } 10 \\
\text { companies with the } \\
\text { greatest benefits }\end{array}$ & $\begin{array}{l}\% \text { of concentration } \\
\text { of profits of the } \\
\text { sector in } 10 \\
\text { companies with the } \\
\text { greatest benefits }\end{array}$ & $\begin{array}{l}\text { Total profits of the } \\
\text { rest of companies }\end{array}$ \\
\hline 2007 & $10.564 .296,64$ & $9.360 .142,68$ & $89 \%$ & $1.204 .153,96$ \\
\hline 2008 & $13.518 .070,28$ & $11.602 .556,90$ & $86 \%$ & $1.915 .513,38$ \\
\hline 2009 & $13.180 .544,48$ & $11.663 .657,82$ & $88 \%$ & $1.516 .886,66$ \\
\hline 2010 & $23.922 .127,64$ & $19.857 .632,54$ & $83 \%$ & 4.064.495,10 \\
\hline 2011 & $23.307 .861,07$ & $18.444 .880,98$ & $79 \%$ & $4.862 .980,09$ \\
\hline 2012 & $25.598 .192,03$ & $19.783 .130,30$ & $77 \%$ & $5.815 .061,73$ \\
\hline 2013 & $23.662 .531,91$ & 16.187.888,18 & $68 \%$ & 7.474.643,73 \\
\hline 2014 & $25.066 .879,59$ & $20.802 .894,00$ & $74 \%$ & $4.263 .985,59$ \\
\hline 2015 & $26.869 .036,44$ & $26.070 .233,53$ & $97 \%$ & $798.802,91$ \\
\hline 2016 & $27.165 .089,91$ & $22.589 .161,83$ & $83 \%$ & $4.575 .928,08$ \\
\hline
\end{tabular}

Source: Authors' results 
In 2015 there are 798.802,91 dollars of the "Total profits of the rest of companies" which are 169 in that year. This figure is unusually low because the company ROCHE had high losses, $\$ 3,317,998.3$, which decreased the total profits of companies in general, and raised the concentration of profits around the ten companies with more benefits.

\section{DISCUSSION}

It should be noted that the decade analyzed consists of two well differentiated periods. The first covers 2007 to 2014 characterized by significant economic growth and a second that includes only two years, 2015 and 2016, motivated by a decline in GDP and fluctuations in the pharmaceutical sector. Under this economic boom, macroeconomic variables increased, such as the percentage of health spending by the public sector on GDP, reaching its peak in 2014. 2014 was also the period that spent the most public health on its whole. However, the year 2013 saw the highest expenditure on private medicine with respect to total expenditure. In 2016 there is a rebound in public sector health spending despite the poor economic situation in the country, possibly due to political reasons, since there were general elections.

During the decade under investigation, the percentage of public spending on GDP has increased significantly. The year with the highest percentage increase over GDP took place in 2013, which does not coincide with the year with the highest percentage of health expenditure over GDP, which was 2014, and so it was invested in other concepts that have not been addressed in the present investigation. However, the year 2014 was the one that more public spending was generated on, in an absolute way. In 2015, spending contracted and in 2016 it picked up again, probably making a special effort for political and circumstantial reasons.

Regarding the percentage of health spending by the private sector on GDP, 2013 was the year with the highest expenditure, decreasing in 2014 and 2015, and slightly increasing in 2016.

In relation to the income of the pharmaceutical sector, the most important year was 2015, possibly due to the long payment periods handled by the public administration to pay its suppliers. On the other hand, profits increased during the entire period analyzed, regardless of the economic situation, and the behavior of health spending or the decrease in the income of the sector.

The Pearson correlation shows that the macroeconomic variables analyzed have a strong relationship. The strongest link is established between GDP and health spending, coinciding with previous studies (Hitiris \& Posnett, 1992; Shi, et al., 2014), which translates into an increase in health expenditure in the good and bad times in times of recession, 2015 and 2016. In terms of profits, they do not have a strong relationship with the variables used. All this is reinforced with the calculation of the regression, where it can be inferred that the utilities require more variables that are not used in this article to be clarified in more detail. Nevertheless the income are explained by the variables taken into account.

The structure of the pharmaceutical sector is clearly oligopolistic coinciding with the world situation (Jiménez \& Hurtado, 2005). In relation to income, dispersion has increased throughout the decade, although it continues to be low. As for the concentration of profits decreased until 2013. Since then they have been increasing year by year. This is due to the increase in companies that show losses in their financial statements, which have grown in number in the second half of the analyzed decade. Particularly noteworthy is the case of the company Roche Ecuador, owned by the Swedish company Roche Fiance Ltd. and the Dutch holding company Roche Pharmaholding BV, which had significant losses in 2014 and 2015. In 2015, losses amounted to 3,317,998, 3 dollars, which distorted the figure of concentration of profits around the ten companies with the highest profits in the sector. 


\section{CONCLUSION}

The level of income of all sectors has a decisive influence on the variables of income of the sector. The variable GDP per capita at current prices explains with $90.8 \%$ the income variables of pharmaceutical companies, which shows the strong relationship of the country's economic situation with the performance of pharmaceutical companies, much more decisive than the health spending at both the private and public levels.

There are two economic cycles clearly differentiated. The period of growth from 2007 to 2014 and the time of economic contraction from 2015 to 2016, which set the pace of health spending, especially from the public sector, which during this decade directed the income and profits of the sector.

The effort made by the Ecuadorian State to reduce the poverty gap among the general population is justified, taking advantage of the good economic situation, increasing the percentage of public spending on health, as well as the change in the productive matrix, demonstrated through the increase in the dispersion of revenues of pharmaceutical companies, despite the fact that their concentration continues to be high. This oligopolistic situation is difficult to fight because the patents belong for twenty years to the large multinationals of the sector according to the TRIPS rules. The legislation imposed by the Ecuadorian government in this regard has served as a barrier to entry for many international companies, which prefer not to operate in the country, which causes the shortage of some advanced medicines, for which there are no generic medicines to replace them within the country.

One of the limitations of the study is that the years of economic recession analyzed are only two in consideration with eight years of economic wellbeing. The study should be completed with future research on the upcoming economic and social situation. In addition, only one industry has been analyzed in isolation with some economic variables, in the absence of thoroughly analyzing each indicator separately.

\section{REFERENCES}

Acebo, M. (2015). Industria Farmacéutica. Estudios Industriales Orientación Estratégica Para La Toma de Decisiones. Retrieved September, 16, 2017 from http://www.espae.espol.edu.ec/industria-farmaceutica/

Ahmadi, N., \& Shahandashti, M. (2017). Comparative empirical analysis of temporal relationships between construction investment and economic growth in the United States. Construction Economics and Building, 17(3), 85-108. doi:10.5130/AJCEB.v17i3.5482.

Baltagi, B.H., \& Moscone, F. (2010). Health care expenditure and income in the OECD reconsidered: Evidence from panel data. Economic Modelling, 27(4), 804-811. doi:10.1016/j.econmod.2009.12.001

Bravo, E. (2014). Determinantes del crecimiento económico con presencia de instituciones públicas en México. Economía Informa, 384, 91-108. doi:10.1016/S0185-0849(14)70412-8

Carriel, J. (2012). Gasto público en salud en el Ecuador. Public expenditure in health in Ecuador. Medicina, 18(1), 5360.

Fedesarrollo Cámara de la Industria Farmacéutica de la ANDI. (2015). Informe del Sector Farmacéutico; 2015. Retrieved October, 4, 2017 from http://www.fedesarrollo.org.co/wp-content/uploads/Informe-Farmacéutico-Julio2015.pdf

Felipe, A. (1998). Uso del estadístico Dn de Kolmogorov-Smirnov en inferencia paramétrica. Trabajos de Estadística, 3(2), 177-194.

Fernández, C. (2017). El impacto de la emigración y de las empresas españolas en la economía del Ecuador (1990-2014). Universidad Rey Juan Carlos: doctoral thesis.

Galindo, M.A. \& Sosvilla, S. (2012). Construcción y crecimiento económico. Economía de La Vivienda en España, 867, 39-50.

González, P. (2015). Análisis Sectorial de la Industria Farmacéutica en Uruguay. Retrieved January, 2, 2018, from http://observatorio.competitividad.edu.uy/files/farma.pdf.

Hitiris, T. \& Posnett, J. (1992). The determinants and effects of health expenditure in developed countries. Journal of Health Economics, 11(2), 173-181. doi:10.1016/0167-6296(92)90033-W 
IQVIA Institute. (2017). The Growing Value of Digital Health. Retrieved October, 28, 2017 from https://www.iqvia.com/institute/reports/the-growing-value-of-digital-health

Jiménez, I. \& Hurtado, R.Á. (2005). La concentración de mercado en el sector farmacéutico colombiano 2002-2003. Un análisis parcial para las enfermedades cerebrovasculares e isquemias, diabetes mellitus y morbilidad. Ecos de Economía, 9(21), 174-202. doi:10.1002/bdm.565

Méndez, V., Méndez, P., Pérez, C. (2015). El impuesto a la renta en el Ecuador 2000 - 2015. Revista Electrónica Iberoamericana, 9(1), 1-26. Retrieved from http://www.urjc.es/ceib/

Miller, R.D., \& Frech, H.E. (2000). Is there a link between pharmaceutical consumption and improved health in OECD countries? PharmacoEconomics, 18(1), 33-45. doi:10.2165/00019053-200018001-00006

OMCE (2014). Informe Sobre El Sector Farmacéutico. Retrieved September, 15, 2017 from https://www.cgcom.es/sites/default/files/informe omc sector farmaceutico oct 2014.pdf

OMS (2014). Estadísticas Sanitarias Mundiales 2014. Retrieved September, 15, 2017 from http://www.who.int/gho/publications/world health statistics/2014/es/

Ortiz, E., Galarza, C., Cornejo, F., \& Ponce, J. (2014). Acceso a medicamentos y situación del mercado farmacéutico en Ecuador. Rev Panam Salud Publica, 36(1), 57-62.

Pérez, C. (2017). Emprendedores y empresa española en Ecuador (1950-2015). Análisis cualitativo del crecimiento socioeconómico de los Andes y el Pacifico. Universidad Rey Juan Carlos: doctoral thesis.

Pérez, C., Fernández, C., Méndez, V., Méndez, P. \& Alvarado, M. (2015). Comunidad Andina de Naciones (CAN), Perú, Colombia, Bolivia y Ecuador: proceso de convergencia y adopción de las NIIF. Revista de Economía y Política, 11(21), 83-97. doi:10.25097/rep.n21.2015.05

PwC. (2012). From Vision to Decision - Pharma 2020. PwC Pharma 2020. Retrieved October, 27,2017 from http://www.pwc.com/gx/en/pharma-life-sciences/pharma2020/vision-to-decision.jhtml

Qian, Y.D. (2007). National Patent Laws Stimulate Domestic Innovation in a Global Patenting Environment? A CrossCountry Analysis of Pharmaceutical Patent Protection, 1978-2002. Review of Economics and Statistics, 89(3), 436453.

Rodríguez, D., Perrotini, I., \& Martínez, M.Á. (2016). Estabilidad del crecimiento de largo plazo en los estados de la República Mexicana: nueva evidencia de pruebas de estacionariedad en panel con rupturas estructurales. Investigación Económica, 75(297), 73-102. doi:10.1016/j.inveco.2016.08.002

SENPLADES. (2013). Plan Nacional Buen Vivir 2013-2017. Retrieved September, 20, 2017 from www.planificacion.gob.ec\%5Cnsemplades@semplades.gob.ec\%5Cnwww.buenvivir.gob.ec\%5Cnwww.buenvi vir.gob.ec

Shi, L., Yang, H.Y., Cheng, G., \& Meng, Q. (2014). Time trends and determinants of pharmaceutical expenditure in China (1990-2009). PharmacoEconomics, 32(3), 257-264. doi:10.1007/s40273-013-0072-3

Simó, J., de Pablo, R., Ramos, M.J., \& Gaztambide, M.S. (2011). ¿Gastamos demasiado en medicamentos? El gasto farmacéutico, un bien de primera necesidad entre los paises europeos. Aten Primaria, 33(5), $244-253$. doi:10.1016/S0212-6567(04)79410-X

Terán, G.J., Terán, B.L., Montenegro, V.J., Realpe, I.A., Villarreal, F.J. \& Fernández, A. (2017). Diagnóstico de las variables del comportamiento organizacional en farmacias de Sangolquí, Ecuador. Revista Cubana de Investigaciones Biomédicas, 36(1), 1-11. 